\title{
LATE EOCENE DIATOMITES REVEAL GULF OF MEXICO BIOSILICEOUS SEDIMENTATION
}

Thomas E. YANCEY, Dept. Geology \& Geophysics, Texas A\&M University

Diane M. WINTER, Academy of Natural Sciences, Philadelphia, Pennsylvania
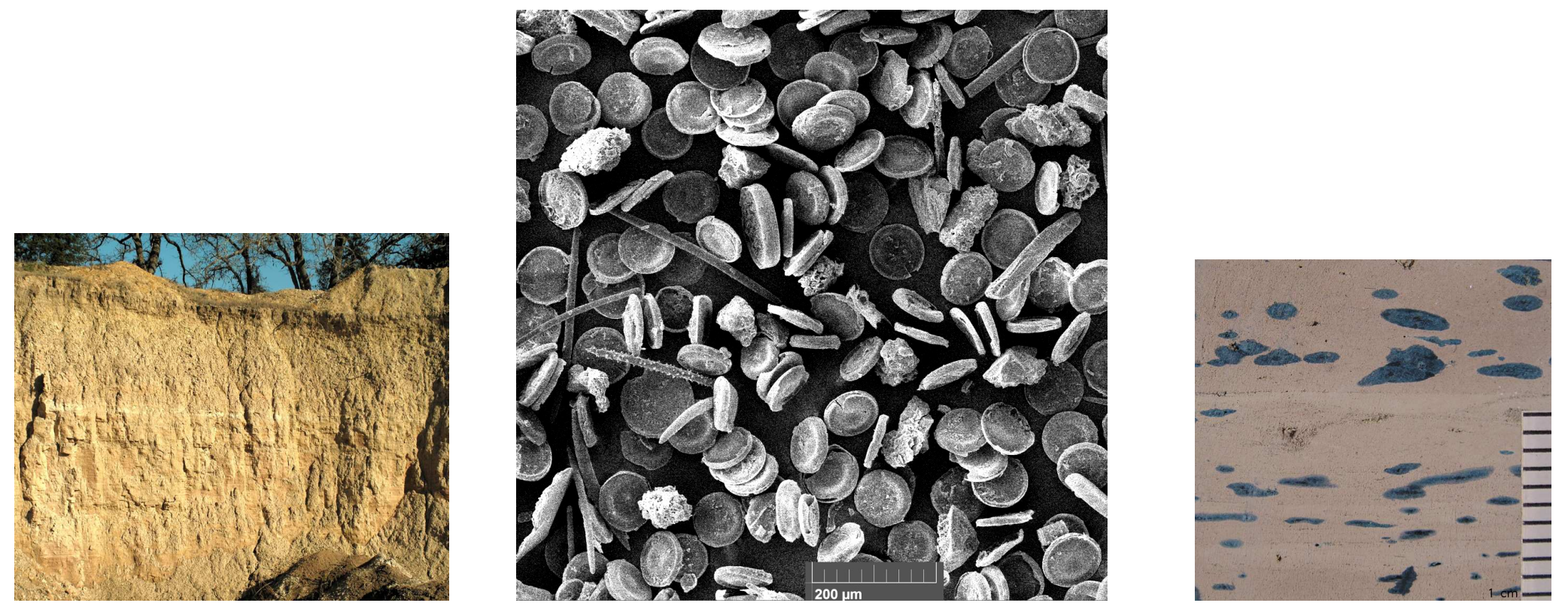


\section{DIATOMITE DEPOSIT}

BALCONES MINERAL CORPORATION, FLATONIA, FAYETTE COUNTY, TEXAS

A unique deposit that has been quarried as an absorbant for many years; yet there is no record of diatomite being present in Texas until last year's report (at GCAGS)
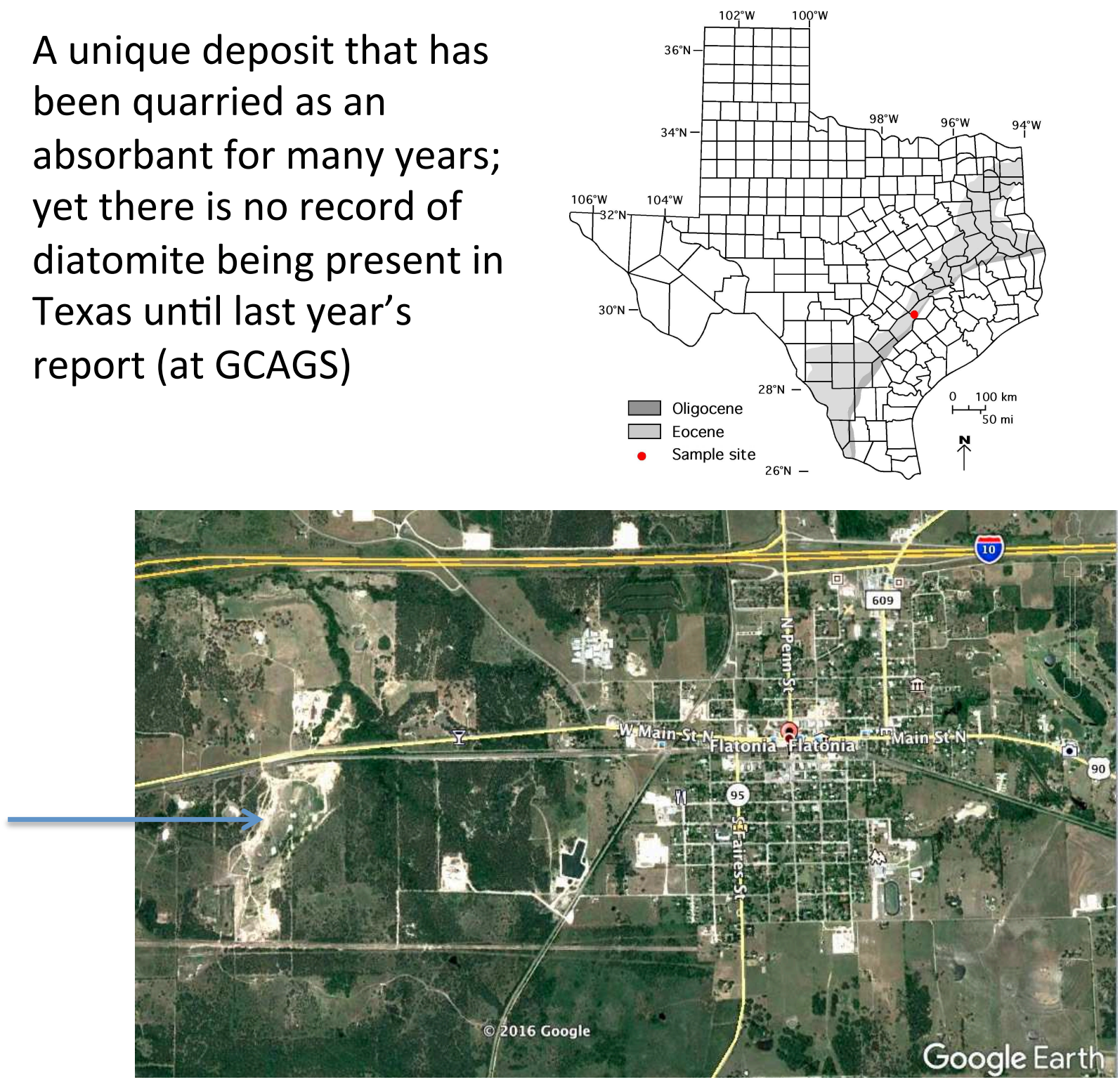


\section{AGE OF DIATOMITE}
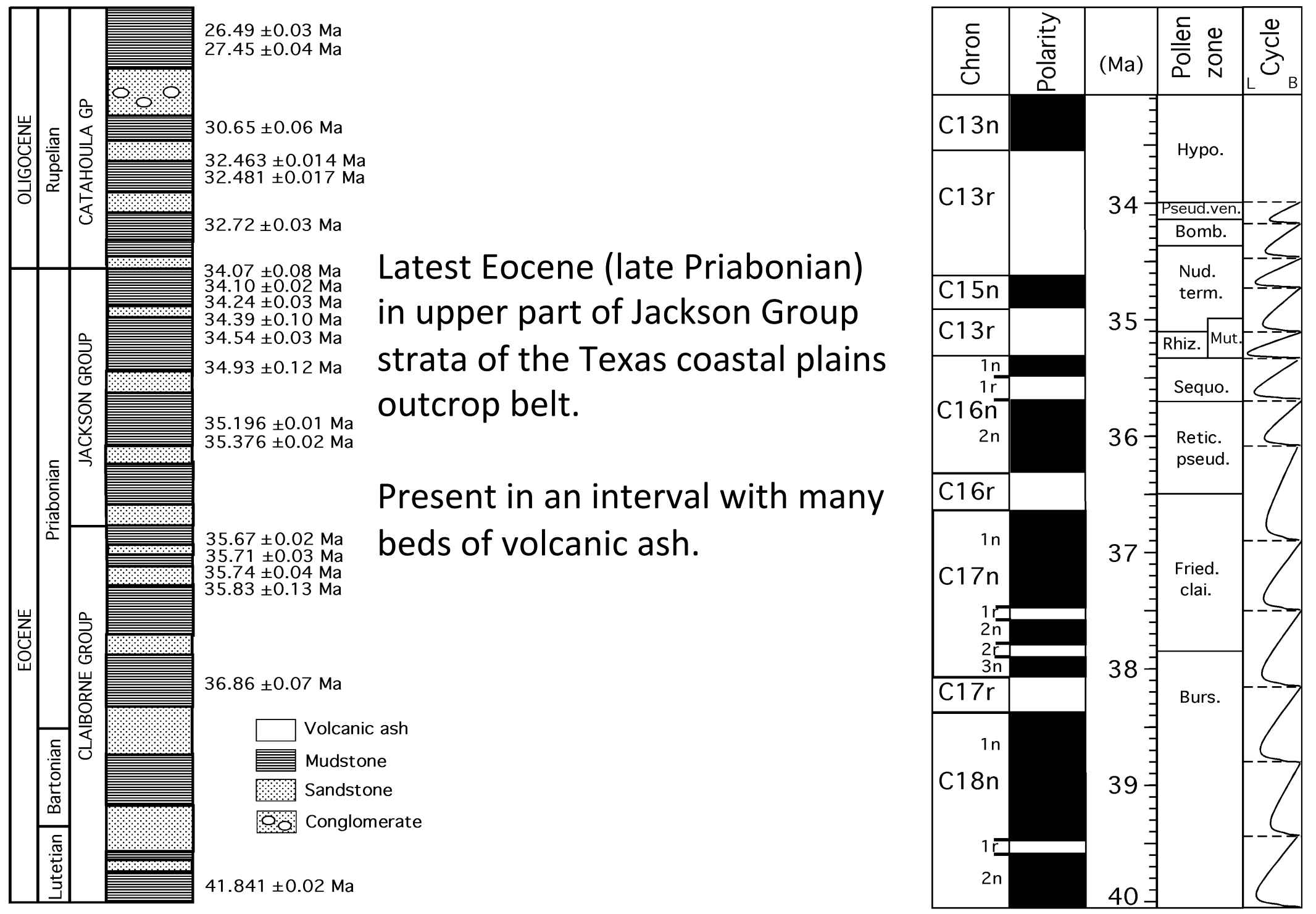

$\mathrm{Ar} / \mathrm{Ar}$ dates of volcanic ash beds (Heintz et al. in part) 


\section{DIATOMITE SEDIMENT}
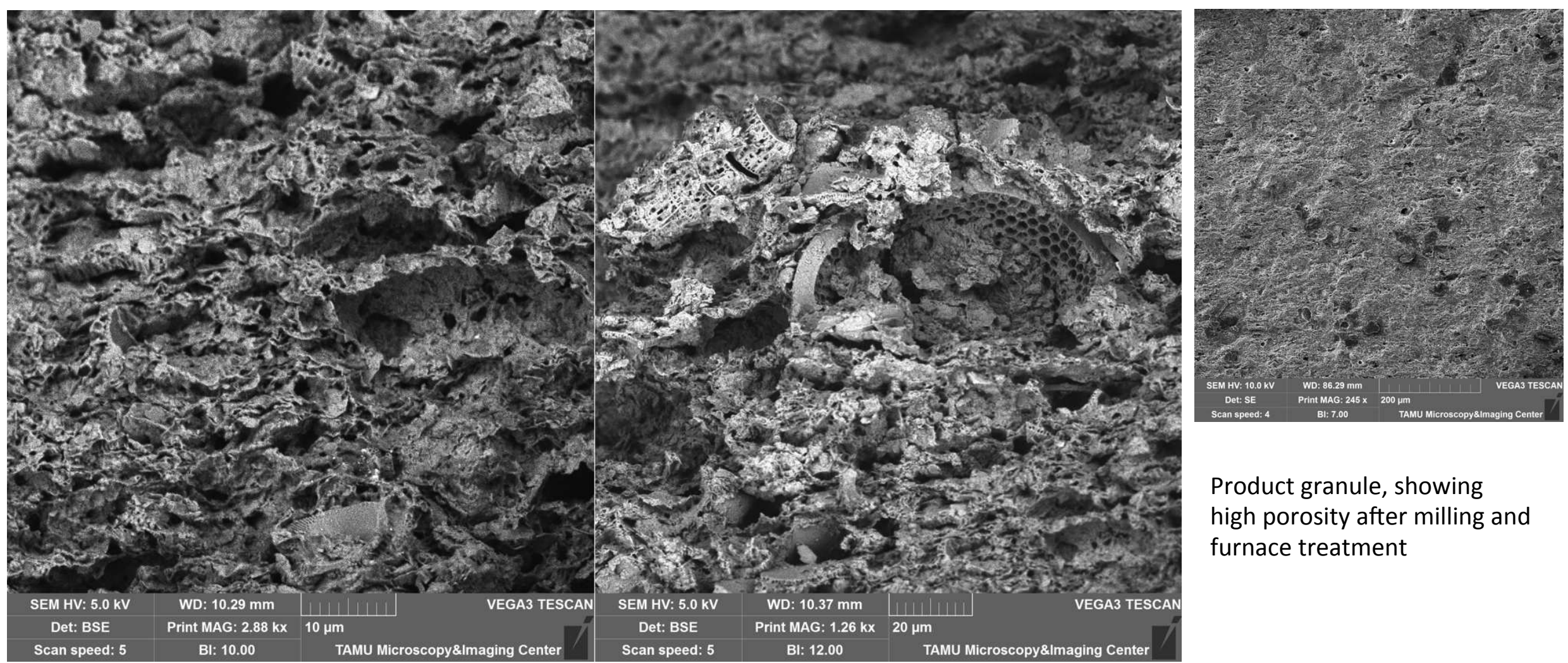

Product granule, showing high porosity after milling and furnace treatment

Diatoms get crushed as mud matrix compacts, but many are sturdy enough to retain form and the sediment retains a porosity of $63-65 \%$ (Data from Doug McCarty, Chevron) 


\section{DIATOMITE MINERALOGY}

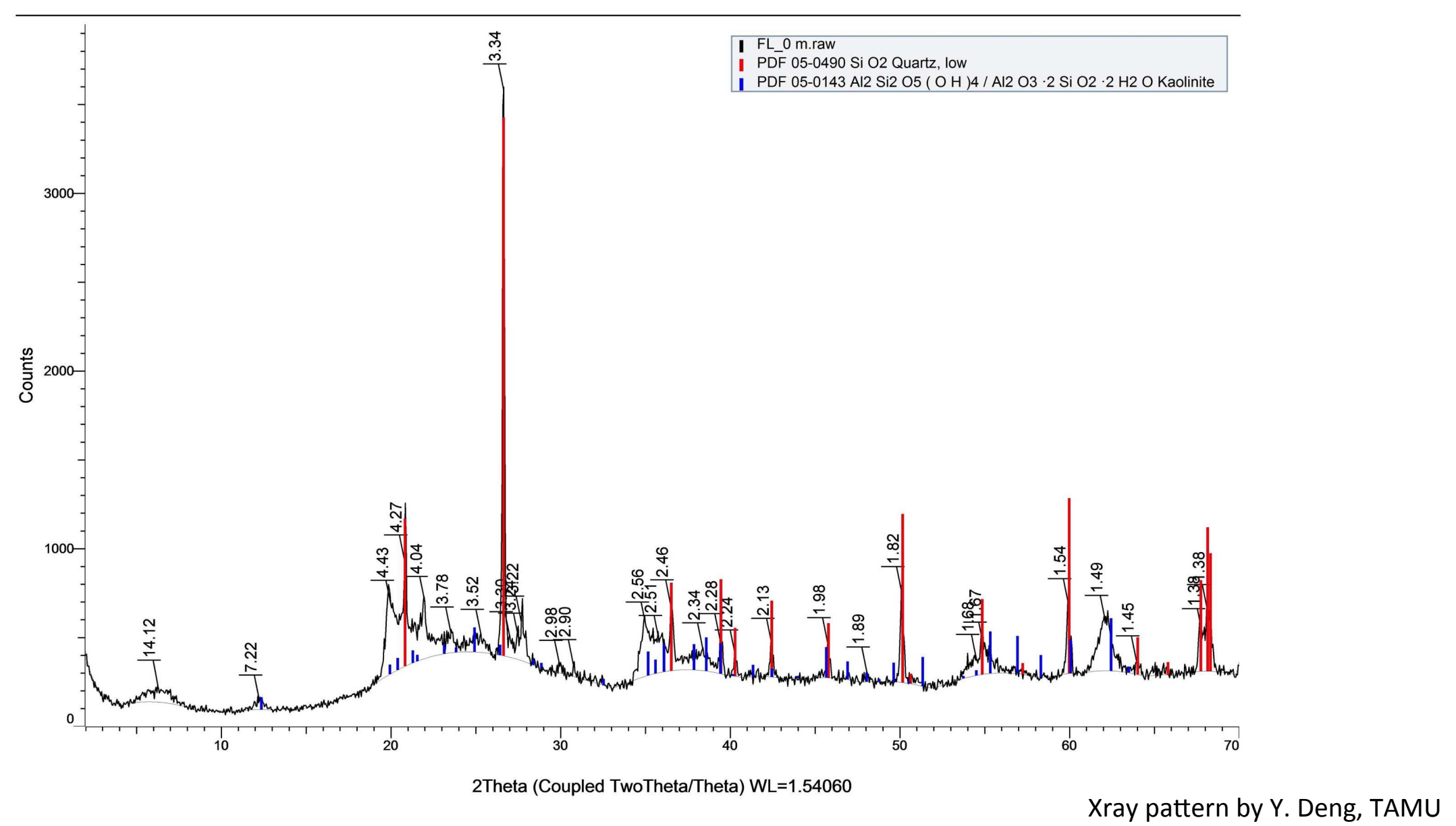

Raised base of pattern reveals high content of opal. Minor smectite clay present, minimal kaolinite. No opal CT present, showing opal not recrystallized. Sharp quartz peak results from admixture of minor quartz sand grain component. 


\section{DIATOMITE SEDIMENT}

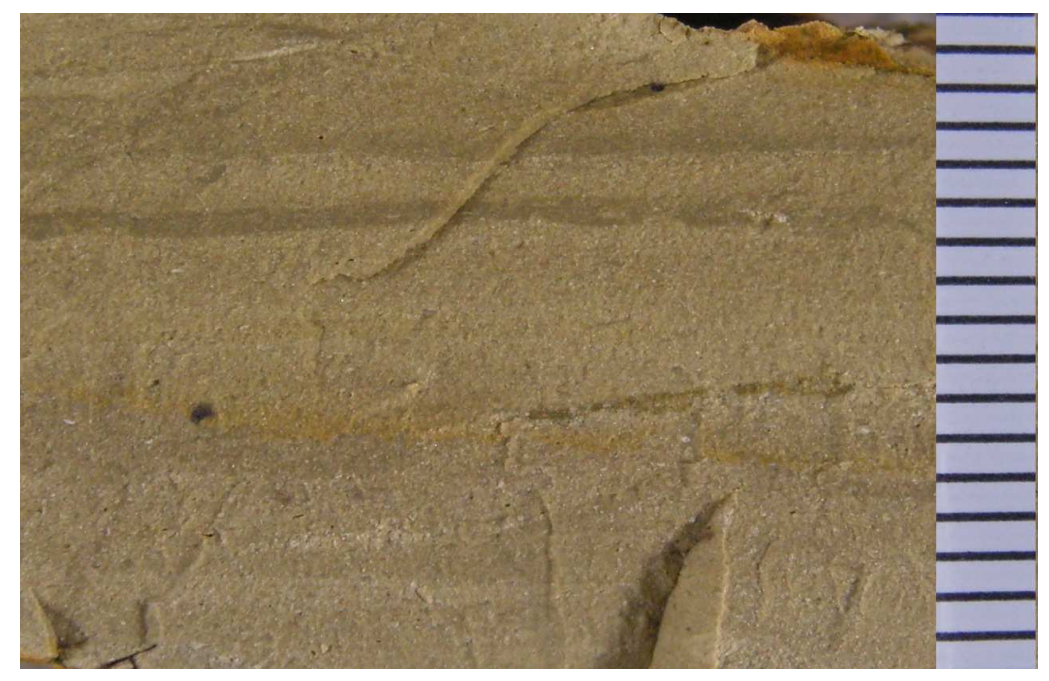

Lamination in diatomite

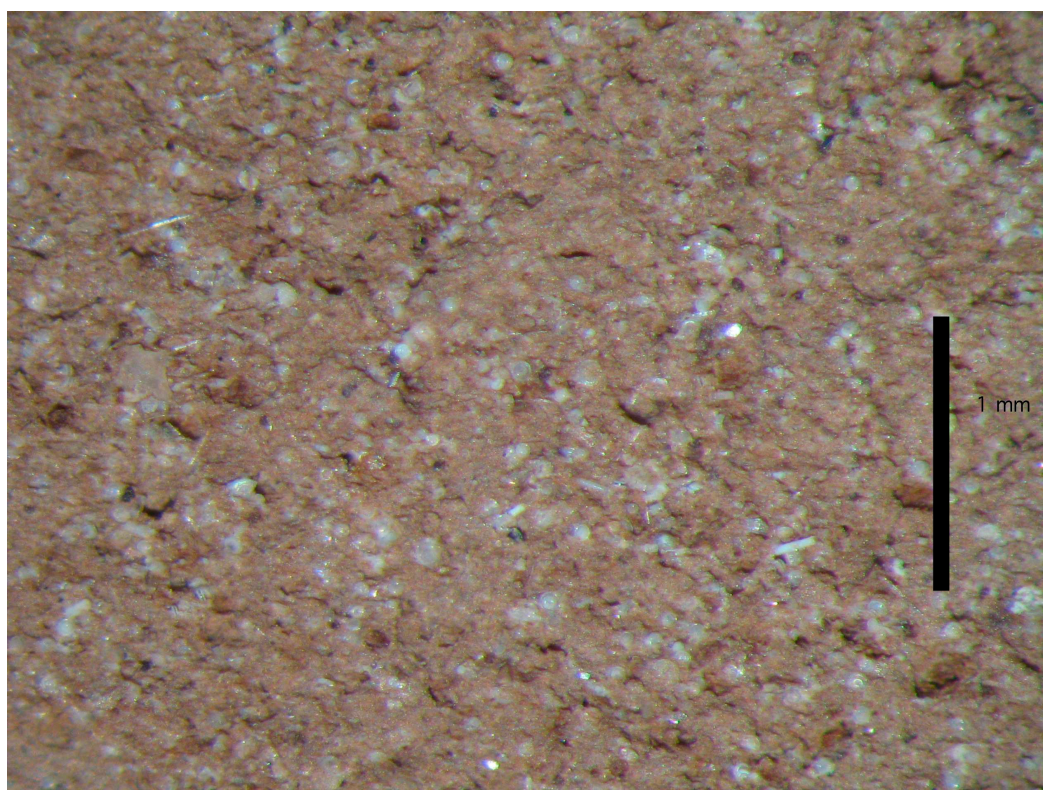

Bedding plane of diatoms \& sponge

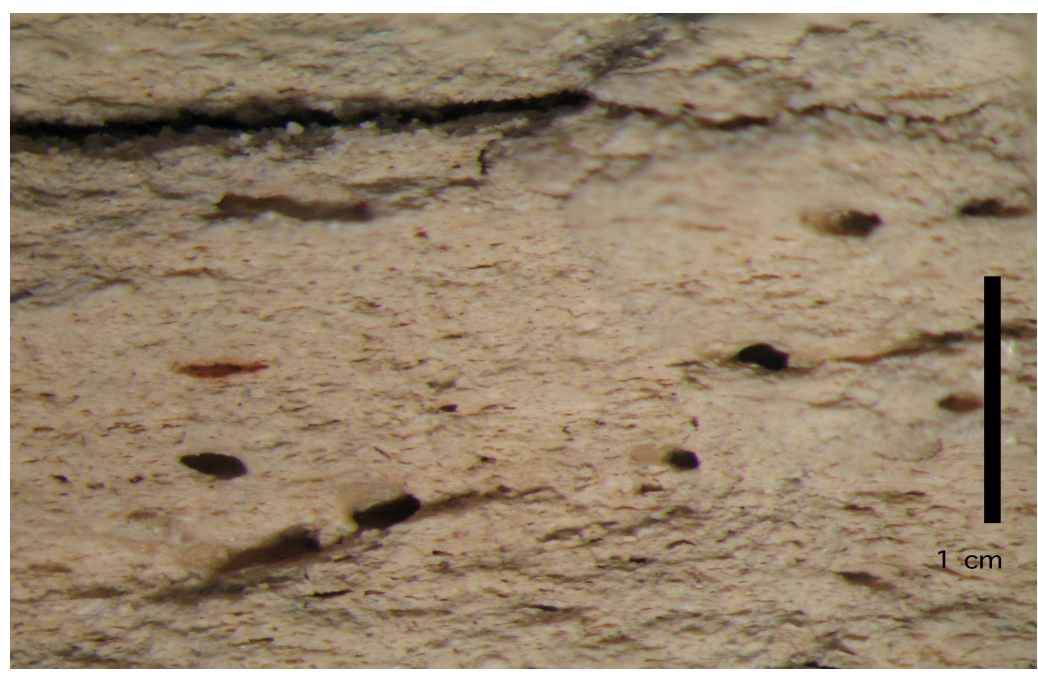

Porosity in diatomite (micro, macro)

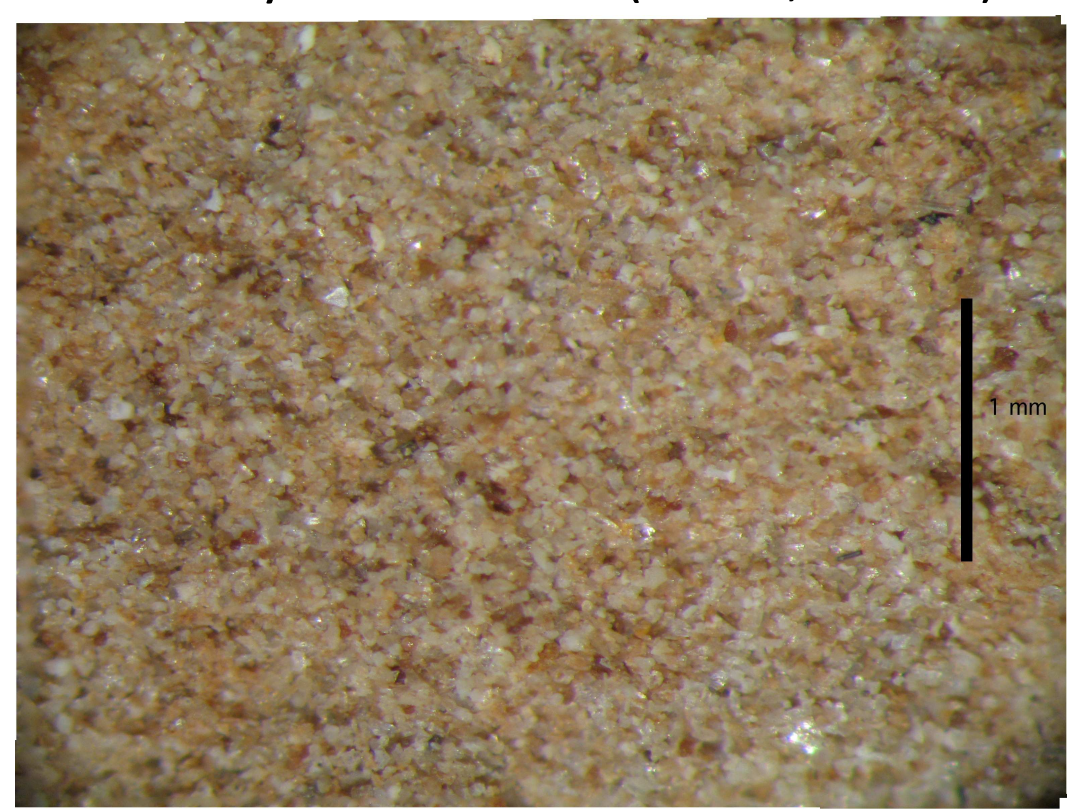

Bedding plane view of sand lamination 


\section{DEPOSITIONAL ENVIRONMENT}

Shoaling (regressive) marine environment, within storm wave base on an open marine shelf; a "coastal" setting
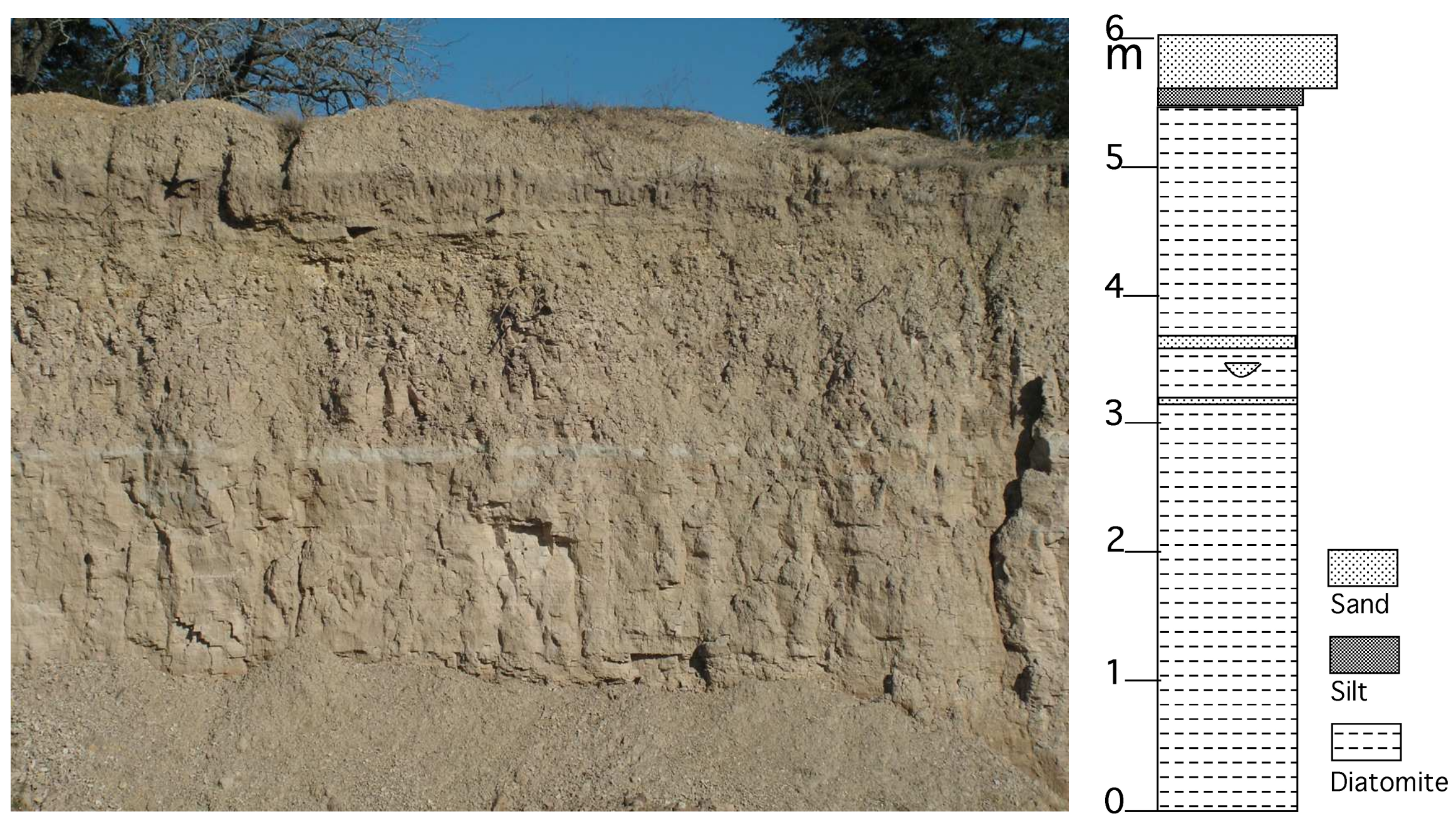


\section{SEDIMENT INDICATORS OF ENVIRONMENT}

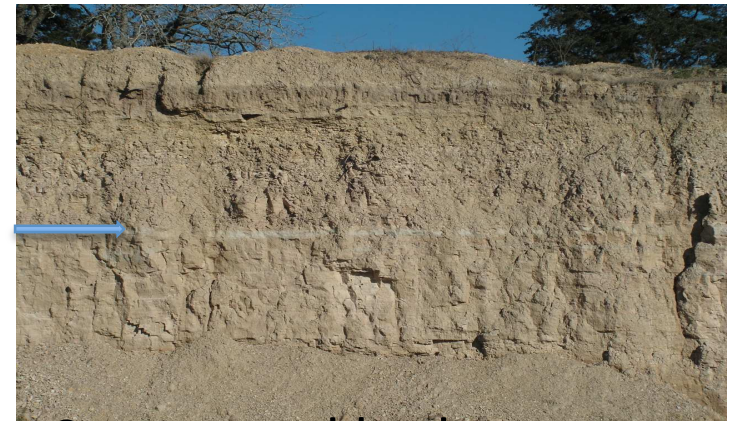

Storm sand bed (extends across

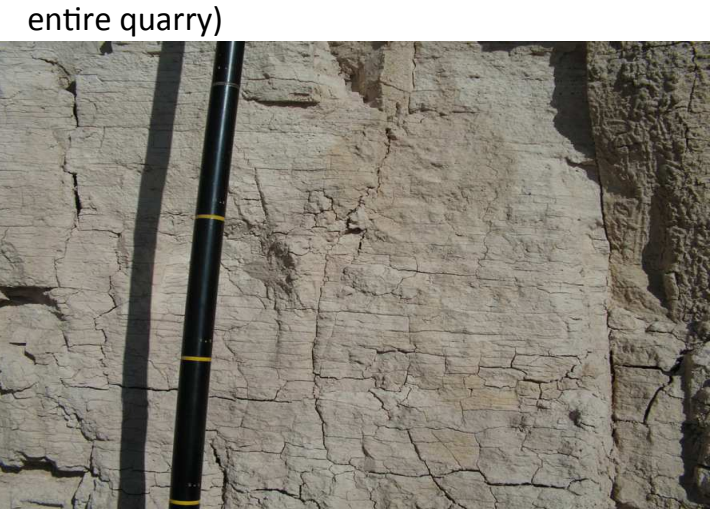

Laminated diatomite

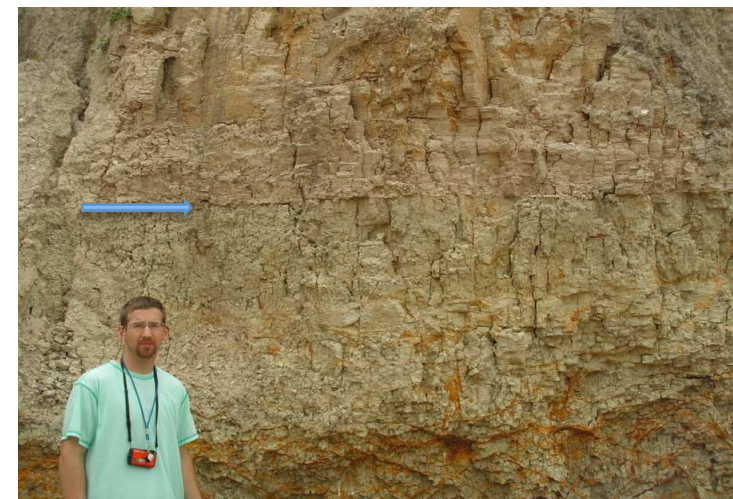

Base of diatomite on clay

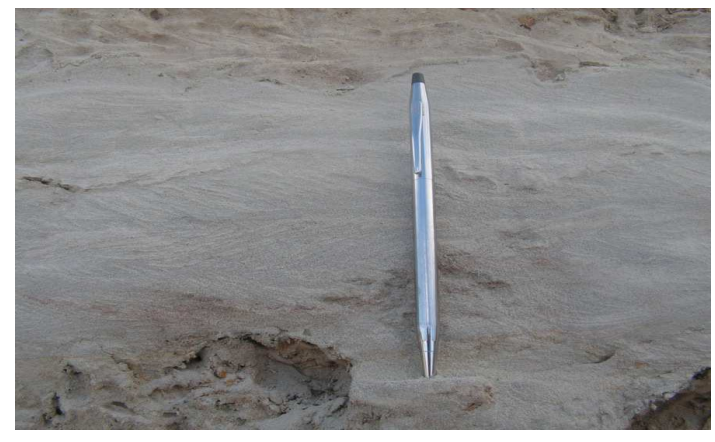

Bidirectional cross bedding (lower shoreface)

Upward changes in sediment and sedimentary structures correspond to shoaling water conditions from below storm wave base to wave-washed shore

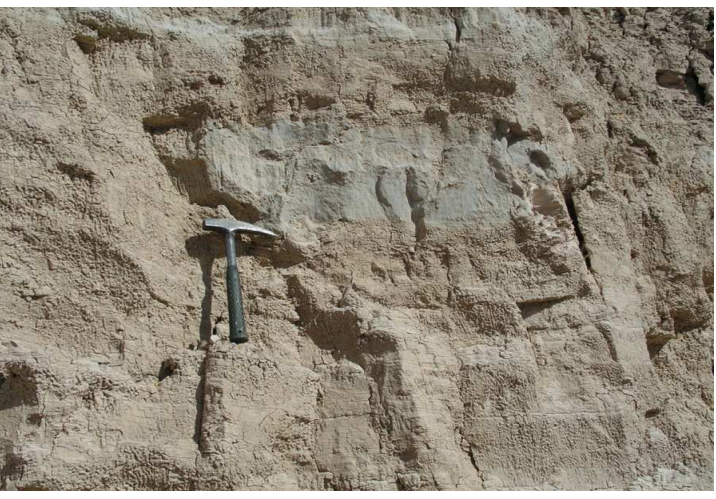

Storm gutter cast

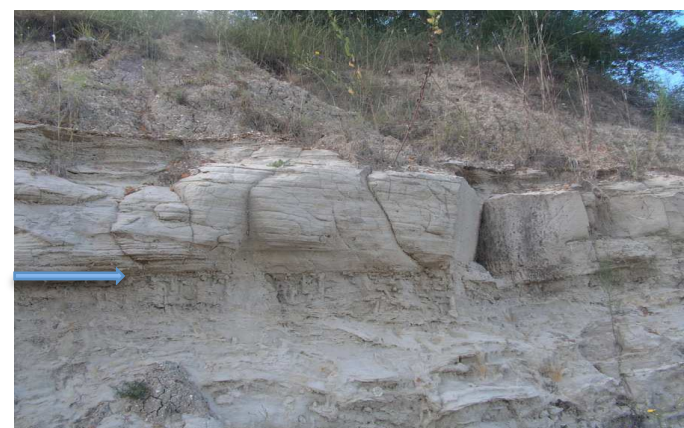

Exposure surface (truncates burrowed sands)

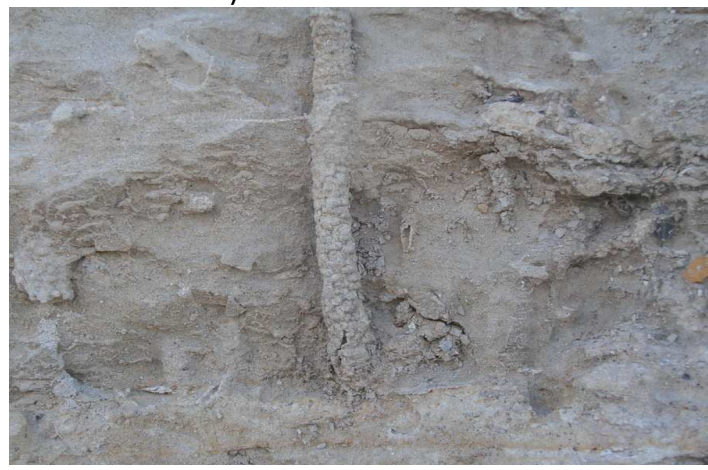

Bioturbated sands (upper shoreface)

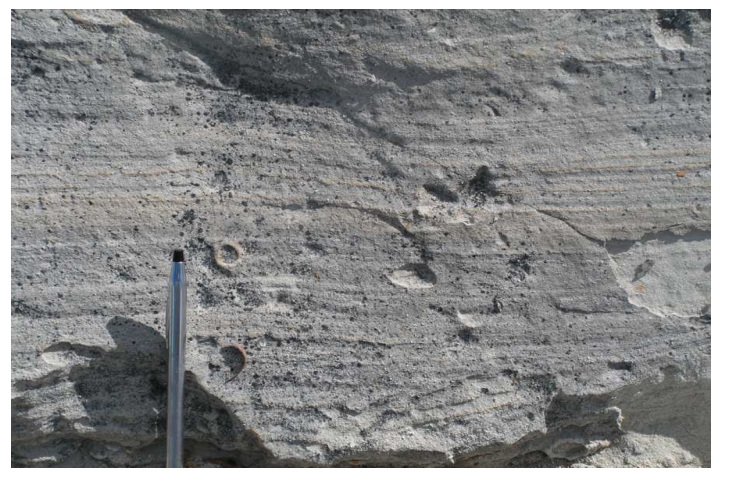

Laminated coarse sand (lower shoreface) 


\section{FOSSIL INDICATORS OF ENVIRONMENT}

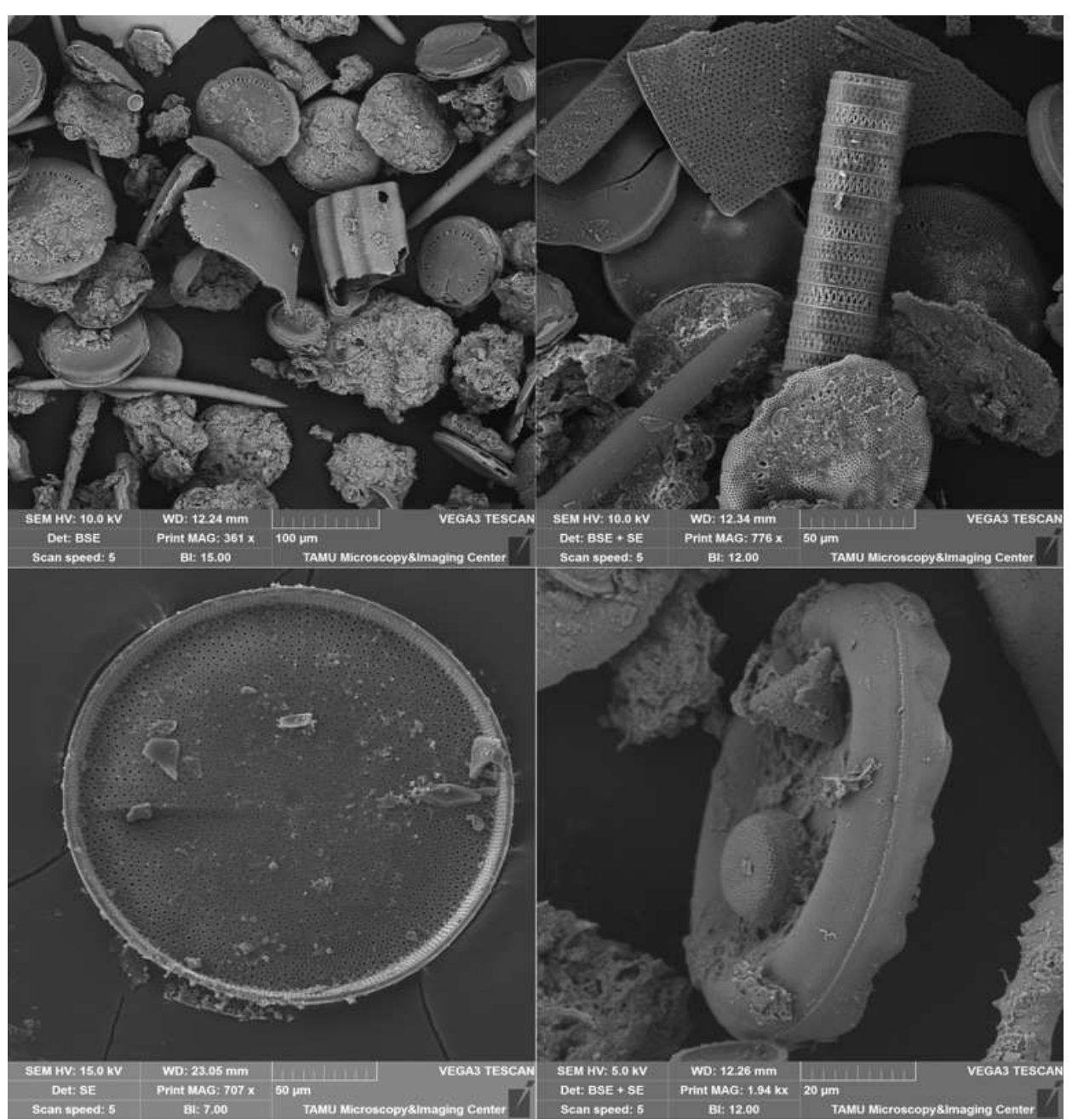

Centric diatoms, marine indicators

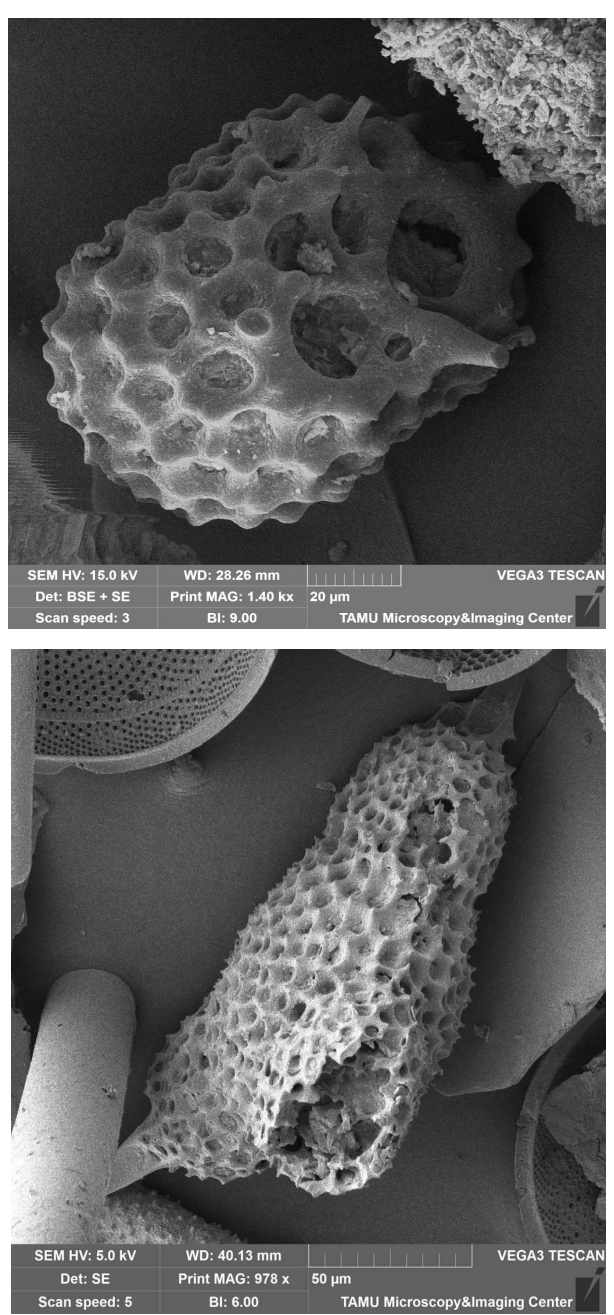

Radiolaria, marine taxa

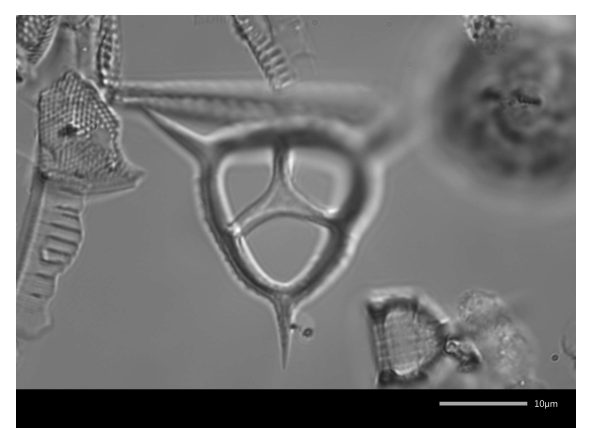

Corbisema, marine silicoflagellate (Diane Winter photo) 


\section{NONMARINE FOSSIL COMPONENT}

Pennales: freshwater diatoms are

a minor component of flora

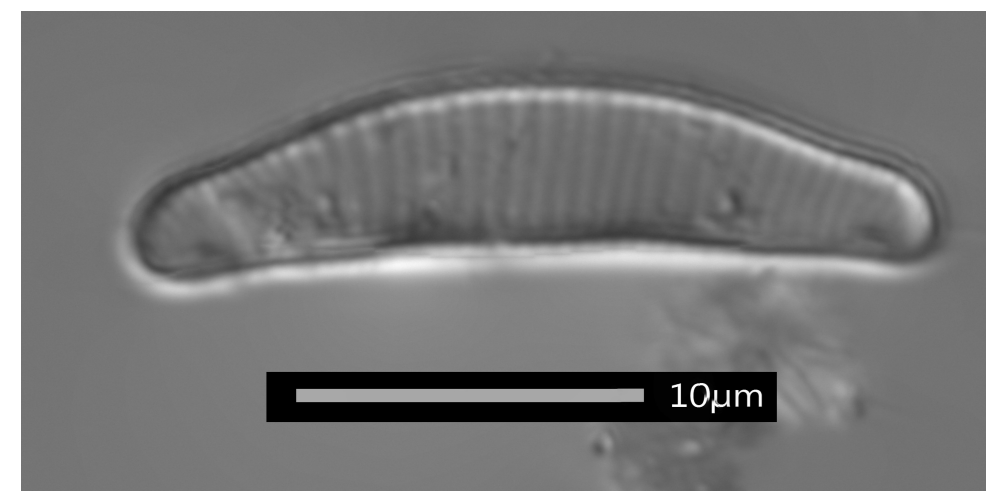

Eunotia sp. (Diane Winter photo)

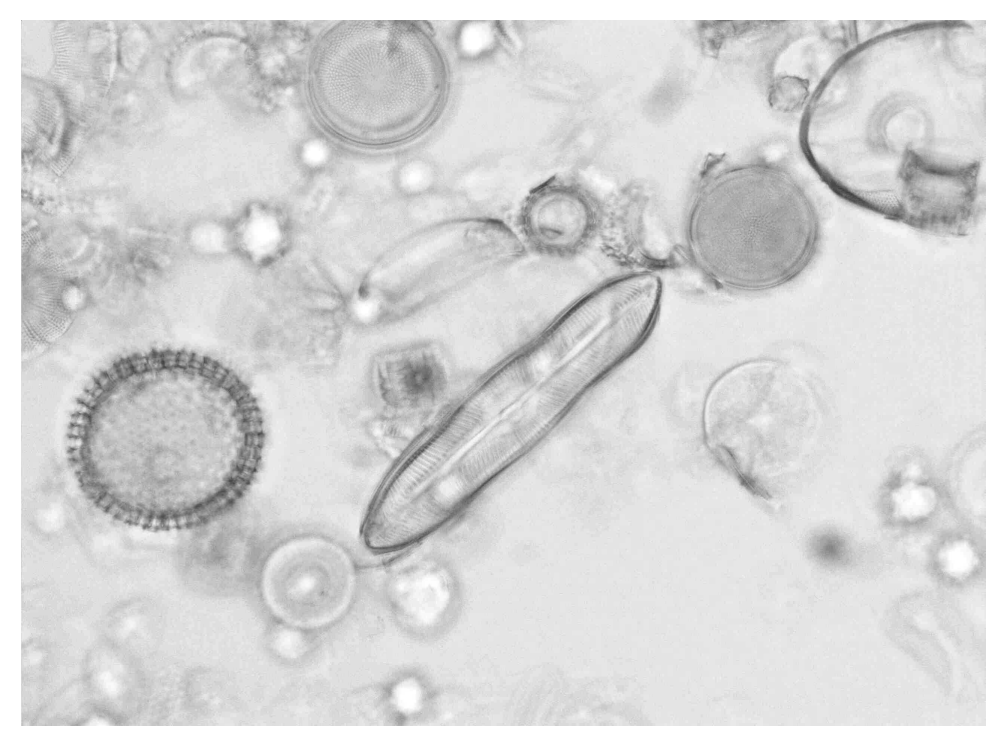

Pinnularia sp. (Ghervy Nzoumba photo)
Phytolith: palm tree origin

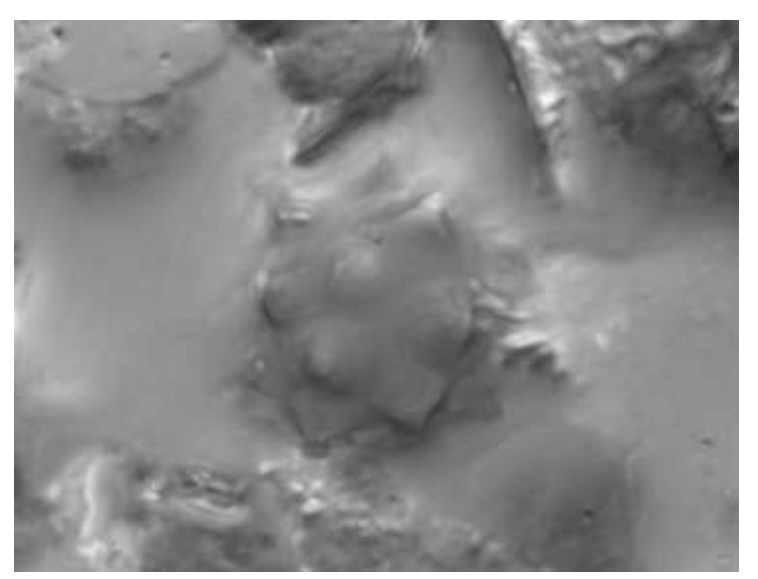

Freshwater diatoms and phytoliths occur in most samples as a secondary component. They show the presence of fresh water input, that is probably the major source of dissolved silica to ocean waters. 


\section{COASTAL MARINE ENVIRONMENT}

Deposited in an inner shelf, coastal marine environment as part of the offshore between fair-weather wave base and storm wave base along a strand-plain, sand-shoreline type of coastal regime.

Inner shelf marine deposits are the most common type of latest Eocene sediment in the outcrop belt of coastal plains Texas.

Periodic Eocene exposure generated diagenetic modification of marine sediments.
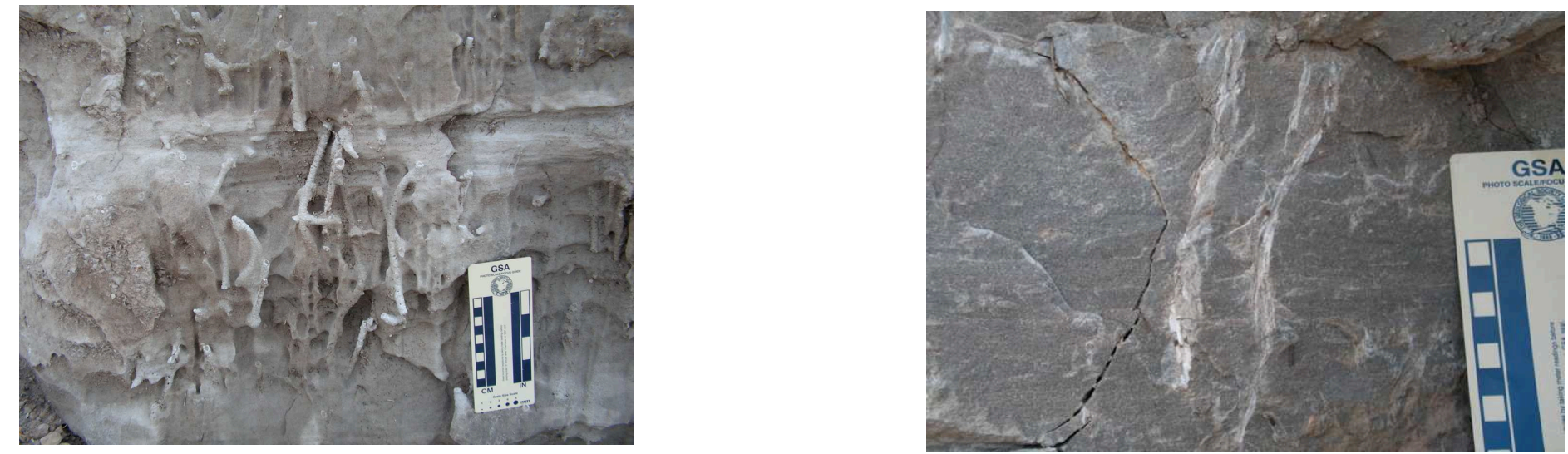

Partly silicified sandstone with Ophiomorpha, Brazos Co., Texas Silcrete rock with opalized roots, Brazos Co., Texas 


\section{DISTRIBUTION OF BIOGENIC SILICA IN LATE EOCENE COASTAL PLAIN}

Although diatomite has been identified only in the Flatonia quarry, biogenic silica is present in ageequivalent strata across all of central Texas.

The map show sites where casual examination of sand-size sediment has revealed biogenic silica. The presence of sponge spicules (large) is an indicator of biogenic silica content.

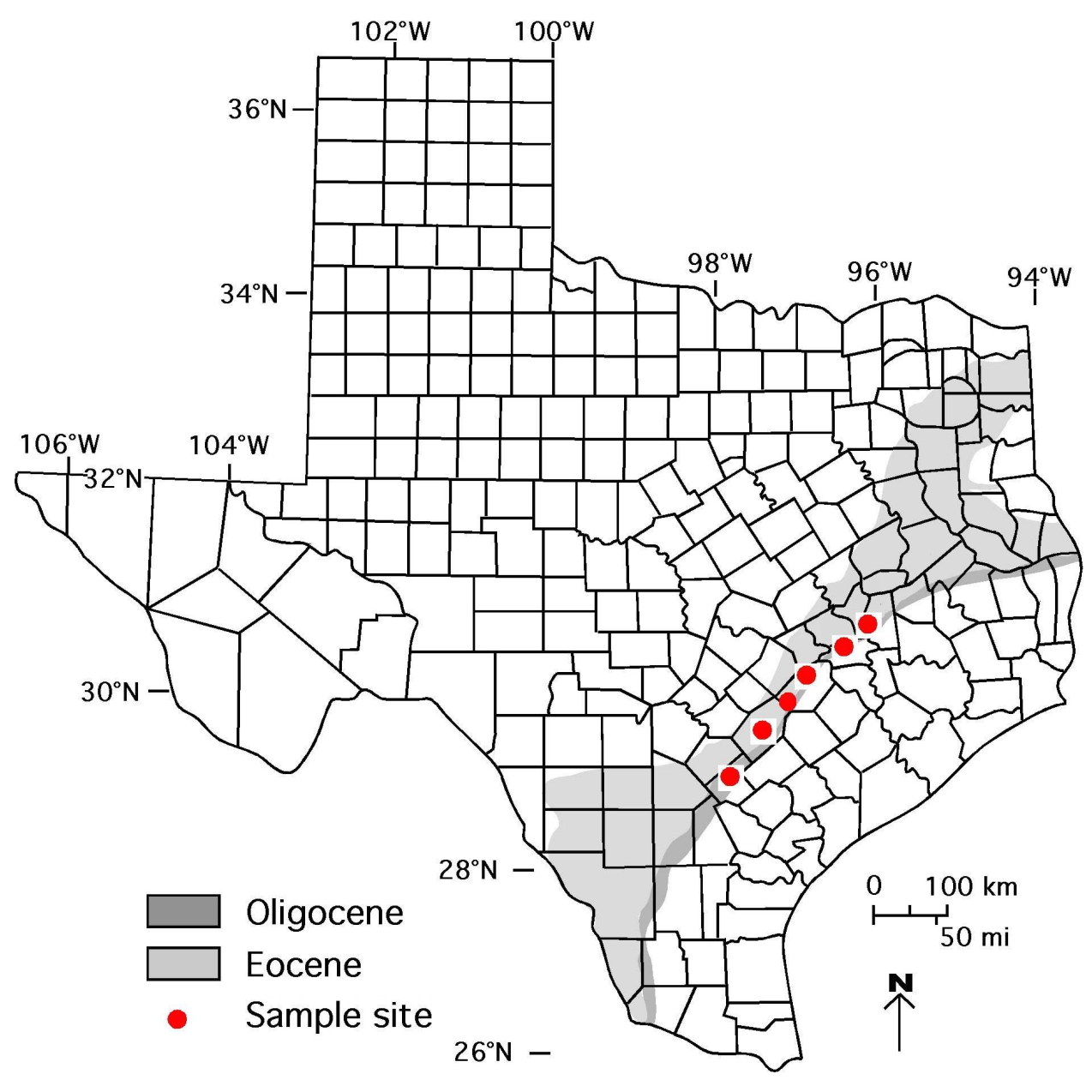




\section{VOLCANIC ASH DEPOSITS}

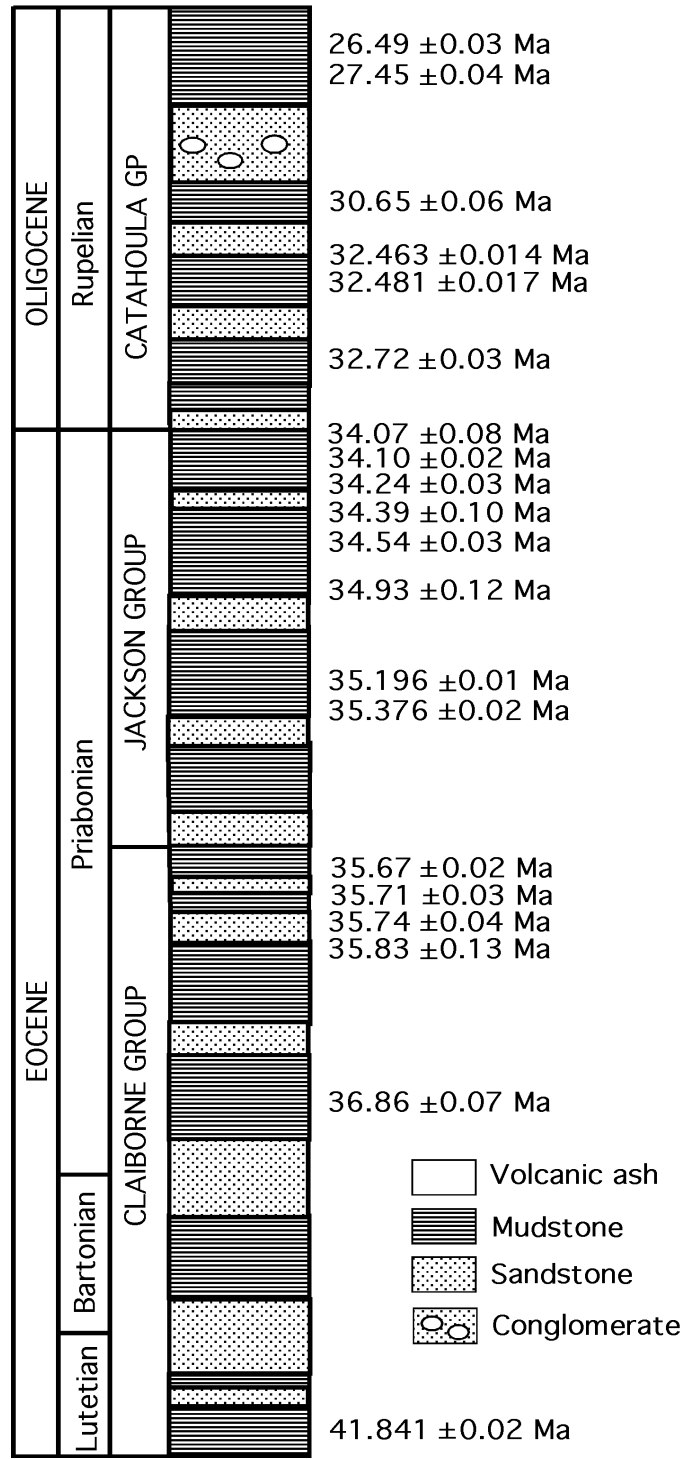

Data partly from Heintz et al.,
Occurrence is related to the deposition of volcanic ash, derived from silicic volcanism along the western margin of North America.

The greatest concentration of ash is present in latest Eocene strata.

Is the source material of commercial bentonites in Gonzales bentonite district.

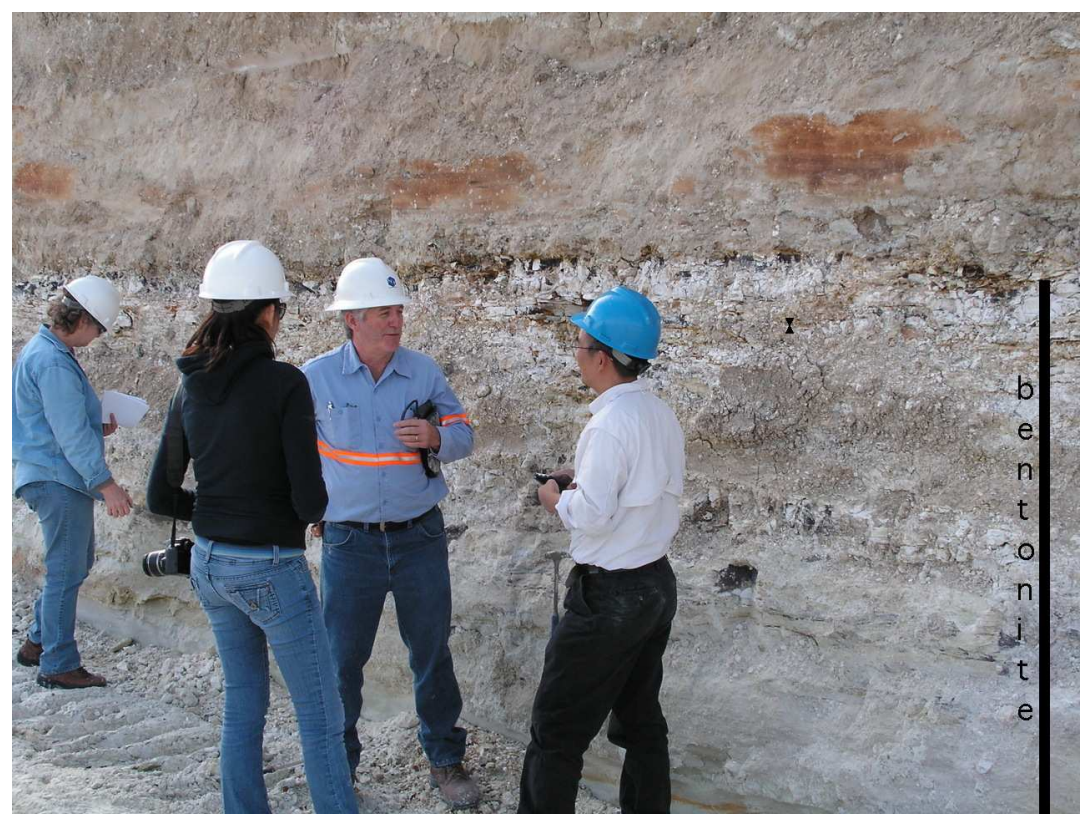

Bentonite quarry, Gonzales, Texas 


\section{SOURCE OF DISSOLVED SILICA}

Weathering of ash glass and mobilizing of silica in ground waters is shown by occurrence of silica-cemented sandstones in sections with volcanic ash.

Presence of fresh-water diatoms and phytoliths is evidence of dissolved silica input from rivers and groundwater.
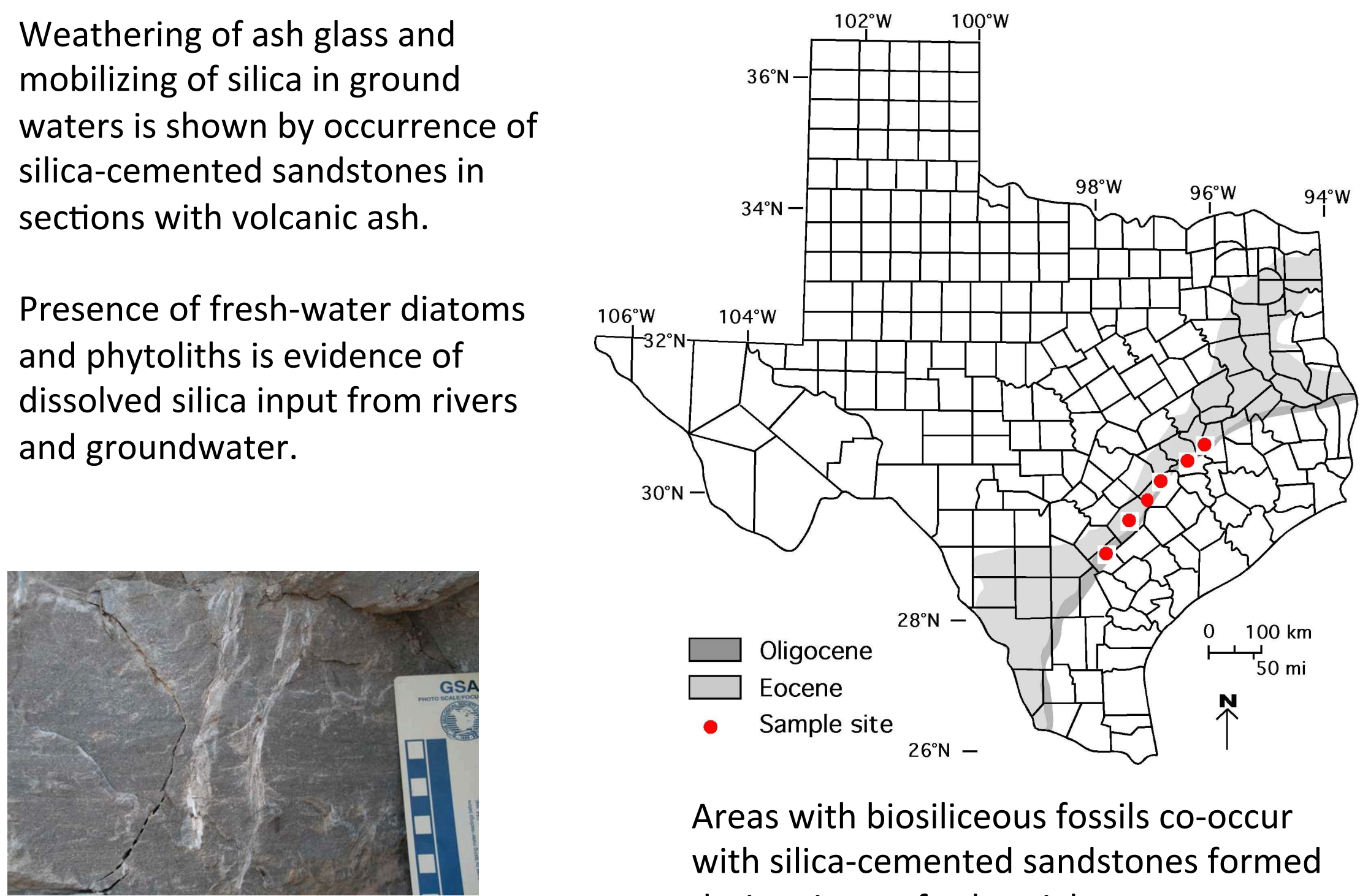

Areas with biosiliceous fossils co-occur with silica-cemented sandstones formed during times of subaerial exposure. (McBride et al., 2012) 


\section{LATE EOCENE BIOSILICEOUS EVENT}

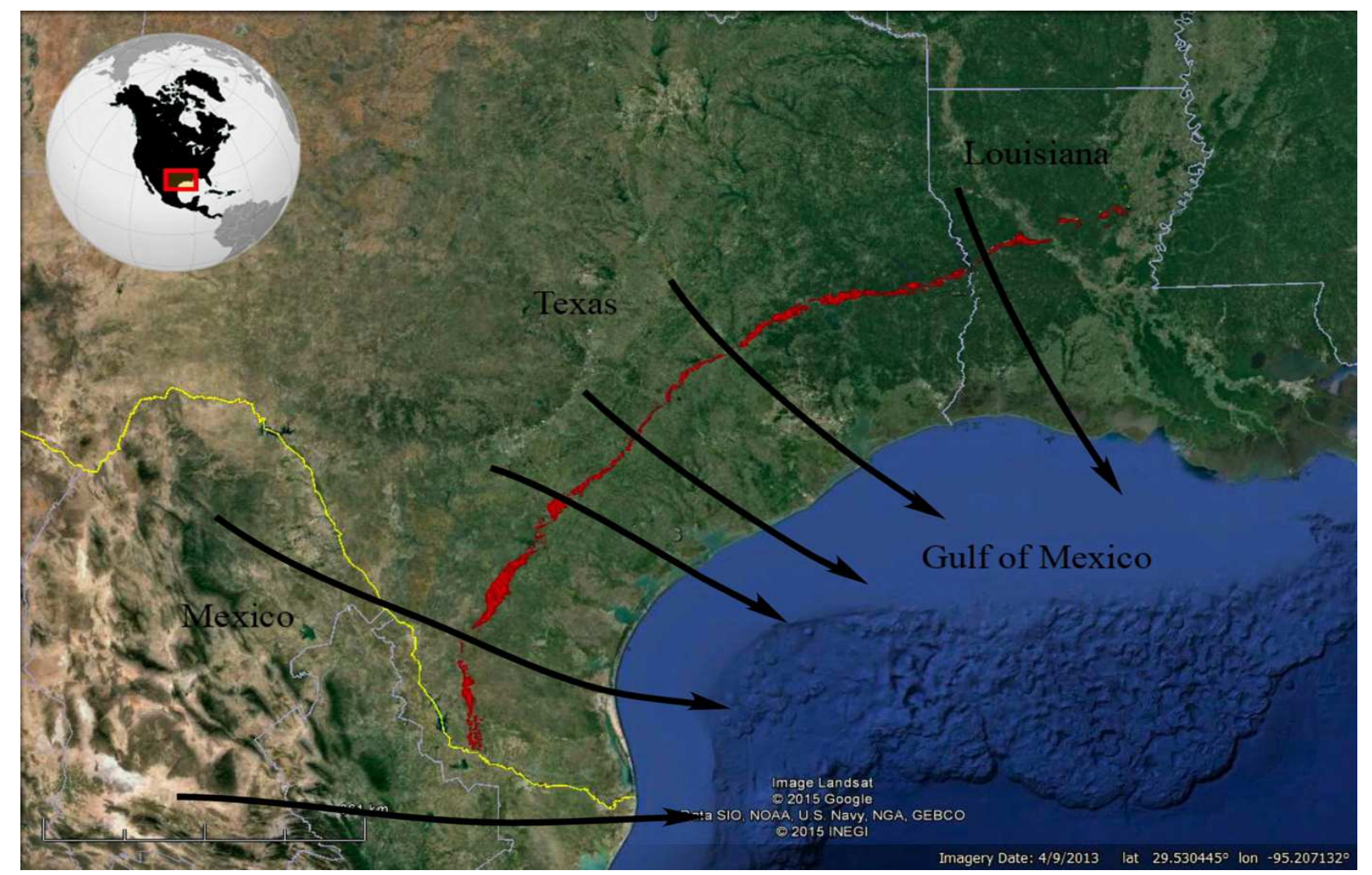

Conclusion: Dissolution of volcanic ash glass shards produced large volumes of dissolved silica that moved into Gulf waters, creating blooms of siliceous benthos and plankton in ocean waters.

These biosiliceous fossils produced a marker that can be expected to show up throughout Late Eocene sediments of the western Gulf. 